\title{
From semi-stagnation to growth in a sino-centric market
}

ANTONIO BARROS DE CASTRO*

According to recent available information, the Brazilian economy may be entering a cycle of sustained growth. The dominant current interpretation points to the progresses made in terms of monetary stability, Balance of Payments and structural reforms. Indeed, without monetary stability and the commercial opening of the economy, investments would not be increasing and credit growth would not be helping the emergence of millions of new consumers. But these achievements should be taken as generally conditioning, rather than actually shaping the new picture. Some unexpected (not rarely positive) consequences of overcoming the long enduring semi-stagnation, the emergence of China as a major player, and its consequences on the necessary re-structuring of the Brazilian industry, seem to be decisive in the present day redefinition of the Brazilian GDP growth potential.

Key-words: semi-stagnation, sino-centric, growth.

JEL Classification: 0, 011, F4.

\section{THE LONG MARCH TOWARDS OVERCOMING SEMI-STAGNATION}

From 1947, when a systematic recording of Domestic Accounting started to be made, to 1980, the Brazilian economy grew at an average annual rate of $7.5 \%$. At that time, the average growth of a group of national economies then considered as underdeveloped was $5.7 \%,{ }^{1}$ while the Japanese economy, the unquestioned growth record-holder, achieved an average expansion of $8 \%$ per annum.

In the very year of 1980 , the Brazilian economy still showed a strong

\footnotetext{
* BNDES, President Advisor, Emeritus Professor, Federal University of Rio de Janeiro. E-mail: abarroscastro@uol.com.br. The author is grateful to Francisco Eduardo Pires de Souza for his criticisms and suggestions. Submitted: April, 2007; Accepted: June, 2007.

${ }^{1}$ This statistic represents the weighted average of the growth rate of 15 Asian and Latin-American economies between 1950 and 1980. MADDISON, Angus La economía mundial en el siglo XX. Fondo de Cultura Económica. México, 1992
} 
expansion, which was, however, widely perceived as unsustainable. From that time until recently growth has been kept somewhat below $3 \%$ per annum, except for some short-term expansive peaks. In this 26 -year period of modest and unstable growth, two sub-periods can be identified.

In a first, long and turbulent phase that goes from 1981 to 1999, the immediate reasons why the Brazilian economy showed itself to be unable to achieve robust growth were quite clear. Thus, from 1980 to 1994, a blend of the so-called debt crisis with high inflation openly explains the modesty and the instability of growth. In 1994, however, the Plano Real defeats inflation, eliminating, consequently, the most flagrant cause of the Brazilian economy's incapacity to grow on a sustainable basis. Despite that, a period of strong deterioration of the Balance of Payments began, which led the current-account deficit to achieve 4.0\% of the GDP in 1998. Within this frame, and aiming at consolidating the victory against inflation, together with the financing and rescheduling of the foreign debt - amidst successive international crises - the monetary authorities chose to keep the nominal interest rate at extremely high levels. In this way a phenomenon emerges which is rare in history: exceptionally high interest rates maintained year after year during a long period. As a consequence, the public indebtedness grew rapidly, exports (damaged by an appreciation of the exchange rate) were kept practically stagnant, and credit (both domestic and international) remained severely constrained. In other words, despite the victory over a chronically high inflation level, powerful factors combined to make steady growth ultimately impossible.

From 1999 on, however, with the successful transition to a free floating exchange rate policy and with the progressive recovery of the fiscal scene (the primary surplus springs from $-0.88 \%$ of the GDP in 1997 to $2.92 \%$ in 1999), a new panorama starts coming to light. It is true that the quality of the resources used to improve the fiscal situation was more than controversial: increases in tax collecting, which highlighted vices in the tax system, ${ }^{2}$ as well as the questionable expedient of reducing public investment. Still, the mere quantitative confrontation of the public deficit, combined with improvements such as the Lei de Responsabilidade Fiscal ${ }^{3}$ [the Fiscal Responsibility Law] reestablished, apparently, the possibility of solid growth.

On the other hand, it is important to highlight that the end of the 1990s meant also the end of a cycle of structural reforms. But the connection between these reforms and economic growth - with the exception of commercial liberalization - is something legitimately controversial. Without deeply

\footnotetext{
${ }^{2}$ The Brazilian tax system, conceived in 1967, suffered — with the passing of time and successive crises - such a number of modifications and corrections that it admittedly became an inconsistent collection full of distortions.

${ }^{3}$ Other advances would unquestionably be necessary. See KHAIR, Amir, AFONSO, José Roberto \& OLIVEIRA, Weder. "Lei de Responsabilidade Fiscal: Os avanços e aperfeiçoamentos necessários". In: MENDES, Marcos (Org.) Gasto Público Eficiente. TOPBOOKS, 2006.
} 
approaching the topic, as it would be a digression from the core of this work, it is worth adding that Brazil was one of the Latin American countries which most went through reforms of the structural kind. ${ }^{4}$

The changes on public policies and the advances on the reforms agenda did not come unaccompanied, though. At this point, it was already possible to notice that the thriving and diversified industry inherited from the period of rapid growth had passed the test of the economy's trade liberalization carried out in the 1990s. This does not mean that there were no losses, especially in the industrial fields with high technological density; it means that the Brazilian industry in large measure preserved the diversity inherited from the period 1950-1980..$^{5}$ Moreover, the metal-mechanical industry, already referred to as the 'Brazilian industrial fortress' ${ }^{6}{ }^{6}$ ended up being clearly invigorated from the liberalization episode. In this manner, the contrast between the Brazilian economy and the other Latin American economies was accentuated, as the latter had been forced by liberalization to specialize, either in the extraction/elaboration of raw products or in the labor-intensive steps involved in the conclusion of industrial processes.

The responses given to the liberalization challenge were to a considerable degree spontaneously decided by the industrial enterprises. Thus, they freely opted for a revision of the management procedures, made severe labor cuts, and fostered modernization, together with quality improvement of products, and (some) change of equipment. The magnitude of this restructuring process (which showed a very high cost as far as employment is concerned) can be evaluated by the exceptional pace of growth in the labor productivity estimated for the transformation industry during the 1990s: something situated between a minimum of $5 \%$, according to the National Accounts, and a maximum of $8 \%$ per annum, according to the Pesquisa Industrial Mensal - PIM [Monthly Survey of Mining and Manufacturing], issued by IBGE ${ }^{7}$ [Brazilian Institute of Geography and Statistics]. It is obvious, however, that this restructuring did not spread all over the industrial

\footnotetext{
${ }^{4}$ FRAGA, Armínio, Latin America since the 90's: Raising from the sickbed. Journal of Economic Perspective, Vol. 18, no. 2, 2004. The article is about the impact of the structural reforms in Latin America, and places Brazil as second in the depth of reforms experienced among the seven strongest regional economies. As for the indicators the author used to examine the reforms, see LORA, Eduardo. Structural Reforms in Latin America: What has been reformed and how to measure it. Inter-American Development Bank, Washington D.C., 2001.

${ }^{5}$ See CASTRO, Antonio Barros de. "A reestruturação industrial do Brasil nos anos 90. Uma interpretação". Revista de Economia Política, jul/set 2001, and KUPFER, Davi, FERRAZ, João Carlos \& IOOTTY, Mariana. "Made in Brazil: Industrial Competitiveness 10 years after Economic Liberalization”. Revista da Cepal. Chile, 2004.

${ }^{6}$ The expression was coined by João Furtado in the article: "O comportamento inovador das empresas industriais”. In VELLOSO, João Paulo dos Reis \& CAVALCANTI, Roberto (Orgs). Cinco décadas de questão social e os grandes desafios do crescimento sustentável. José Olympio, 2004.

${ }^{7}$ GONZAGA MIBIELLI, Paulo. As causas do aumento daprodutividade na indústria brasileira nos anos 90. PhD Dissertation, Instituto de Economia, UFRJ, 2000.
} 
apparatus. In fact, firms in the sector of basic inputs, for instance, didn't need any technological improvement to be kept close to the state of arts.

Considering all the improvements observed at the macroeconomic level, as well as the intense modernization of the manufacturing companies, it is possible to affirm that from 1999 on, the persistence of low growth is no longer easily explainable. Furthermore, the expansion initiated months after the substantial devaluation that followed the transition to the floating exchange rate policy (January 1999), seemed to indicate that the economy had recovered its capacity to grow. As a matter of fact, expectations concerning the performance of the economy remained very optimistic until March 2001 (when the expansion completed a 6-quarter period). Immediately afterwards, however, an exceptional conjunction of adversities put a sudden end to the expansive outbreak.

The collapse of expansion at that time combined problems originating in the country itself (such as the suddenly revealed incapacity to satisfy electrical energy demand) with others coming from abroad, such as the overwhelming economic free-fall in Argentina: a contraction of $4.4 \%$ in 2001, and of $10.9 \%$ in 2002 . The collapse also made it clear the persistent vulnerability of the economy - which had a devastating effect on the business community mood. More precisely, firms, specially those in the industrial sector, were led to conclude that the domestic market was still subject - just as in the two last decades of the $20^{\text {th }}$ century to harsh contractions. In fact, the difficulties faced in 2001, followed by new crises, both in 2002 and in 2003, showed that the economy had not yet found its path to expansion. And the overall picture would still suffer the threatening deterioration occurred in the end of the second FHC's (President Fernando Henrique Cardoso) term in office, when inflation rose to a yearly rate of $29 \%$ in the last quarter of 2002.

The extreme worsening of expectations, besides jeopardizing investments, made it very hard at that point to handle the public debt issue. It had been some time since the financial resource holders demanded extremely high interest rates (and very short terms) for the refinancing of a rapidly increasing volume of debts. In addition, the proportion of dollar denominated public debt reached $50 \%$ in June 2002, remaining above $50 \%$ until February 2003. At that point, many were questioning the sustainability of the advances recently accomplished at the macroeconomic level, and even believing that the situation had reached a point of no return.

However, the new government, which took office in January 2003, faced the incipient inflationary burst with severity and efficacy, managing to quickly reassume control over the situation. It is not easy, thought, to evaluate the cost of the victory over the so-feared inflationary set back. It is true that trust within the financial establishment was largely regained. The problem, however, was that after two years of extremely modest growth (the economy grew $1.3 \%$ in 2001 and $2.7 \%$ in 2002), the first year of the new government showed a $1.1 \%$ growth rate! Moreover, families' consumption was reduced by $0.7 \%$ in 2003 . Similar results unquestionably contributed to reducing the initial enthusiasm for the new 
government, weakening, in particular, the strong initial support from non-financial enterprises.

It is important, thought, to call the attention to other important (and positive) changes that occurred in the difficult period that the economy went through from 2001 to 2003.

Firstly, let us point out that the renewed frustration as with the performance of the economy, together with the substantial increase in the exchange rate, pushed manufacturing firms towards a broad-based reevaluation of their strategies. The most visible aspect of this repositioning consisted in the bigger share given to foreign market in sales planning. Nonetheless, it was not only about searching for spaces in other less unstable markets than the domestic one. Data related to foreign sales indicate that, at least since 2003, various segments of the Brazilian industry realized that they were able to conquer new markets abroad. There is no doubt that the floating exchange rate, by facilitating the depreciation of the Real, contributed to the advance of exports - but it is important to highlight that the increase in productivity which took place in the previous decade, as well as certain stimuli provided by public-sector policies, were also behind the outstanding results achieved.

It is presently clear to many that trade liberalization decisively contributed to an authentic change of competitive dynamics in the Brazilian market for manufactured goods. Once the gap, in both costs and (mainly) quality towards goods produced in the traditional centers were nearly eliminated, however, firms started discovering that such advances did not suffice. That is to say, the effort made in updating products and processes, even if more effective than passive reestructuring (limited to cutting waste and personnel), was not sufficient to hold market positions. In short, the mere elimination of the initial gap was not in itself reassuring, given that in several segments new products were quickly being introduced in the market. It became more and more clear to many that it was necessary to acquire innovative capability in order to compete. In this sense, an increasing number of companies began an effort towards redefining or even literally creating (new) products, markets and business models. ${ }^{8}$

Regarding the repositioning in the market, however, it is necessary to stress that, paradoxically, the legacy of over 20 years of semi-stagnation seems to have also benefited the adoption of new and more creative standards of behavior. After all, in the mini growth cycles experienced by companies, new opportunities were in many instances opened up - but could not be properly explored. It can be presumed, then, that there were hypothetical innovations on hold, that is, waiting for an opportunity to be explored. ${ }^{9}$

\footnotetext{
${ }^{8}$ The first broad investigation of the competitive strategies of Brazilian manufacturing industry is found in DE NEGRI. João Alberto \& SALERNO, Mário Sérgio (Orgs). Inovações, padrões tecnológicos e desempenhos das firmas industriais brasileiras. IPEA, 2005.

${ }^{9}$ CASTRO, Antonio Barros de. A Hipótese do Crescimento Rápido e Sustentável. VELLOSO, João
} 
With the rapid expansion of exports and some increase in investments (including investments in intangible goods), a new frame began to emerge. Specifically, the Brazilian economy, which already had a powerful exporting agribusiness,$^{10}$ proved increasingly able to compete for spaces in several manufacturing markets. Summing up: macroeconomic conditions, which have undeniably been improved (and could de benefited by further growth), was removing from the scenario the spectrum of high instability. At the same time, exports and investments allowed for the development of new growth opportunities.

Graph I, below, shows the extraordinary performance of Brazilian exports, even when compared with the strong growth in worldwide exports. To this frame it must be added that foreign direct investments seemed to also endorse the incipient expansion of the Brazilian economy. In fact, in the year Brazil got closest to a new and vigorous growth (2004), foreign direct investments in the country leaped from US\$ 10.1 billion to US\$ 18.2 billion.

Graph I:

Brazilian/Word Exports, in quantum (2000-100)

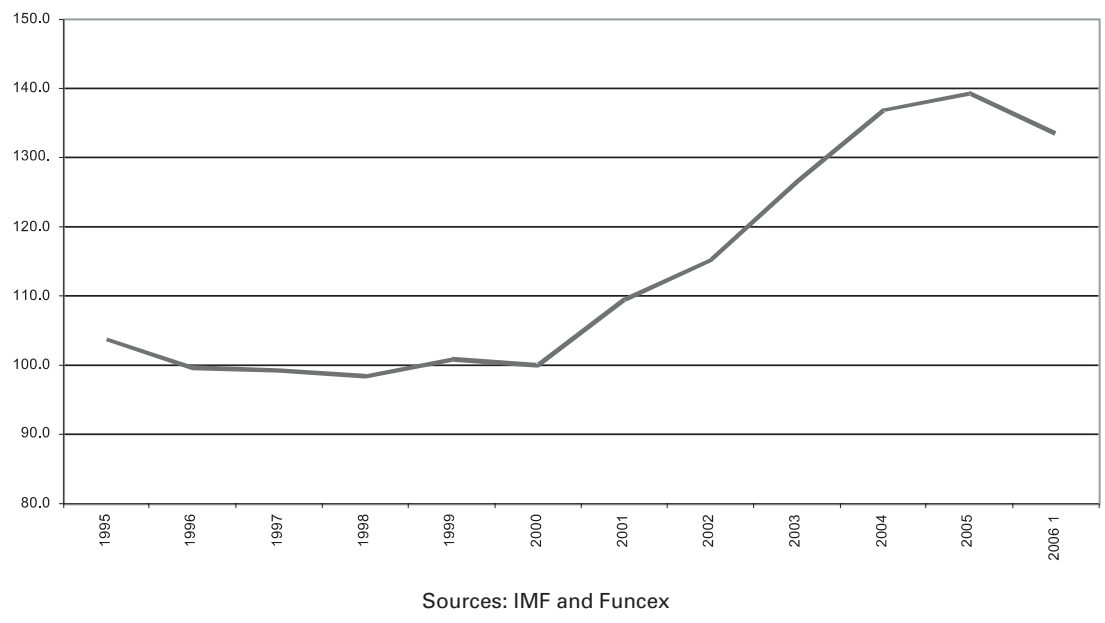

But the improved conditions for an effective resumption of economic growth still counted on other aspects, which are worth highlighting. With this intention,

Paulo dos Reis \& CAVALCANTI, Roberto (Orgs). Cinco décadas de questão social e os grandes desafios do crescimento sustentado, José Olympio, 2005.

${ }^{10}$ Agribusiness is not going to be in focus here, but it is important to point out that this large and diversified sector was a pioneer in growing by incorporating technical progress. BARROS, José R., RIZZIERI, Juarez \& PICHETTI, Paulo. "Effects of Agricultural Research". In: BARBOSA, Marisa. Impacts of the Agricultural Sector Technological Change on the Brazilian Economy. EMBRAPA SGE, 2002. 
let us start by pointing out that in severely fighting inflation and keeping the public debt (which dropped from $52.4 \%$ to $44.9 \%$ of the GDP between December 2003 and December 2006) under control, the new government proved that price stability had become (or was becoming) a permanent goal for the country. In other words, price stability had become a public good, thus changing from the status of a government task to the condition of a State duty. ${ }^{11}$ This change definitely contributed to reinforce the tranquility with which the (in principle) difficult transition between FHC's and Lula's administrations took place. After all, the new government brought new players to power, many of whom came from union activism or originally radical leftist groups, as well as a political party that was extremely critical of the country's institutions and policies. ${ }^{12}$

Many detected inconsistency in the preservation, by the new government, of the macroeconomic policy agenda, as well as in the relevance given to the issue of price stability. The new administration's deep commitment with social inclusion though, made it clear that the continuity (at the macroeconomic level) was being combined with the deepening of changes in a sense or direction that is undeniably consistent with the expectations held in relation to Lula's government. We particularly refer here to the fact that the reduction of inequalities that started by the end of the second FHC's term in office was assumed and intensified by the new government. From the profusion of data indicating this shift we select here two indicators. Inequality, measured by the Gini Index, dropped 4.6\% from 2001 to 2005 (see Graph II), whereas the ratio between the incomes perceived by the $20 \%$ richest and the $20 \%$ poorest declined $21 \%$ in the same (brief) period of four years. ${ }^{13}$ In any case, the massive inclusion of the poor in the consumption of manufactured goods - demonstrated by several indicators - by widening the market's pyramid base, could be preparing the terrain not only for vigorous growth, but for growth of a different kind (a topic to be contemplated further on). The Brazilian press, by the way, has been referring recently to the 'Chinese growth' in consumption by classes ' $\mathrm{D}$ ' and ' $\mathrm{E}$ '.

\footnotetext{
${ }^{11}$ There was, in the past, rapid growth together with high inflation Brazil. But it is important to stress that the institutional regimen adopted in 1964-68 (in the eve of the period of very rapid growth) allowed, to a certain extent, economic calculation, and, given the extension of the indexation, limited to a residue the expropriation associated with high inflation.

${ }^{12}$ A similar combination of discontinuity, at the political level, with continuity in the broader options of economic policy, seems to have happened in Latin America only in the Chilean transition to democracy.

${ }^{13}$ Data was obtained from PAES DE BARROS, Ricardo, FOGUEL, Miguel \& ULYSSEA, Gabriel (Orgs). Desigualdade de renda no Brasil. Uma análise da queda recente. IPEA, 2007.
} 


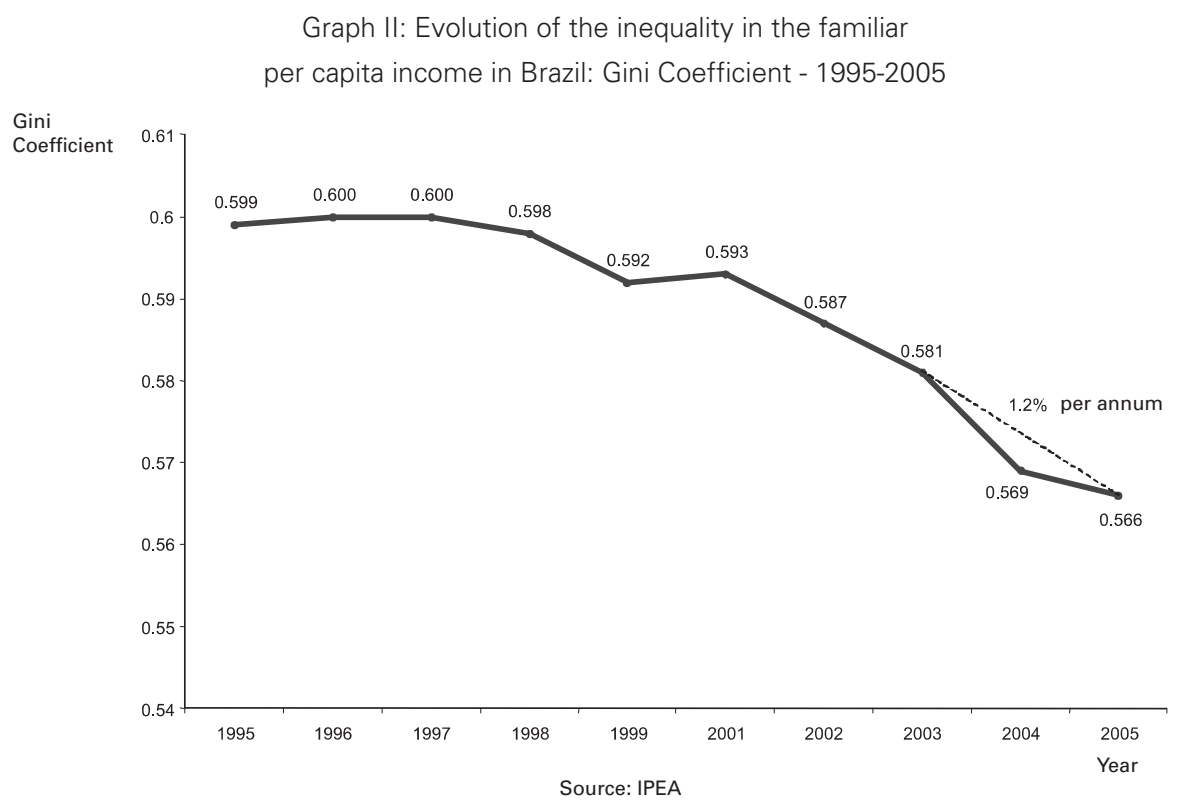

Still the Semi-Stagnation?

The crop of successes harvested in 2004 appeared to many to have put the economy on the tracks of a new expansion cycle. And this was not only due to brisker growth. In 2004, when the GDP displayed a respectable increase of 5.7\%, it also showed traces of a new pattern of expansion. For instance: the volume of exported manufactured articles grew $26.1 \%$, while their prices went up by $5.9 \%$, indicating that the exporting companies could strongly expand their foreign sales, despite a rise in the average price of their products. As for gross capital formation, it rose $9.1 \%$ in that year, showing that the economy was creating additional capacity at a pace very superior to its own (and substantial) rate of growth. In other words, the expansion started to spill over to the future.

Furthermore, simultaneously with the leap in manufactured goods' export rate, there was an yearly jump in imports of intermediary goods ( $21 \%$ in quantum), indicating that companies were intensively taking advantage of the openness of the economy to nurture their exporting offensive. A figure to illustrate the vigor of this offensive: in 2004, Brazil was responsible for $48.5 \%$ of the Argentine imports of electrical and electronic goods. ${ }^{14}$

We list (in Table I) the segments which most contributed to industrial growth in 2004. The list reveals clearly the presence, with a leadership role, of sectors of

\footnotetext{
${ }^{14}$ Data on quantum originate from FUNCEX, and information about electrical and electronic goods is from IES (Sectorial Economic Investigations), VALOR, January 27th, 2007.
} 
relatively sophisticated industries, from a technological point of view. It should be underlined that the contribution to growth given by the three first sectors (automotive vehicles, machines and equipment, electronic material, and communication equipment) is far superior to their weight in the structure of industry, evincing their important role in the expansion observed that year. By contrast, the modest contribution to the industrial growth of natural resources processing activities should also be noticed. This means that, in a flagrant contrast to what was going on in several other emerging economies, manufacturing transformation activities — with a growth of $8.5 \%$ in 2004 - were, in more than one sense, heading the expansion.

Table I: Sectors that contributed to the formation

from $75 \%$ to $80 \%$ of the Growth Rate of the Industry in 2004.

\begin{tabular}{|c|c|c|c|}
\hline Sector & Contribution & $\begin{array}{l}\text { Accumulated } \\
\text { Contribution }\end{array}$ & Weight $^{1}$ \\
\hline Automotive vehicles & 30.4 & 30.4 & 9.2 \\
\hline Machinery and equipment & 11.7 & 42.1 & 6.5 \\
\hline $\begin{array}{l}\text { Electronic material and communication } \\
\text { equipment }\end{array}$ & 7.6 & 49.7 & 3.9 \\
\hline Food & 5.5 & 55.2 & 12.0 \\
\hline Other chemical products & 5.4 & 60.6 & 7.0 \\
\hline Metal products - excluding machines & 4.0 & 64.6 & 3.6 \\
\hline $\begin{array}{l}\text { Office machines and information } \\
\text { technology equipment }\end{array}$ & 3.4 & 68.0 & 0,9 \\
\hline Rubber and plastic & 3.4 & 71.4 & 3.9 \\
\hline Textile & 3.3 & 74.7 & 3.0 \\
\hline Cellulose and Paper & 3.2 & 77.9 & 3.7 \\
\hline Other & 22.1 & 100.0 & \\
\hline Total & 100.0 & & 53.7 \\
\hline \multicolumn{4}{|l|}{ Memo: } \\
\hline Industry Growth Rate & & 8.3 & \\
\hline Real effective exchange rate $(93=100)$ & & 134.8 & \\
\hline
\end{tabular}

As, on the other hand, agribusiness and mining businesses continued to prove to be highly dynamic, there were plenty of reasons to assume that the country might be able to embark on a steady route of expansion. Seen from this point of view, the good results that the economy was recently showing might be seen as a preview of what was coming. Within this framework, the "unlocking" of decisionmaking processes - particularly in the investment sphere — started to be seen 
as a major task for public policies. In contrast to the until-recently prevailing agenda, which was centered on monetary policy and structural reforms, this meant an enormous change. Ultimately the main challenge now was to adjust the expansion pace of the economy, to the musculature of its enterprises.

Despite the substantial widening in the range of actions suggested by this change, it is important to call attention to the fact that the new agenda did not consider issues related to the course or direction of growth. In other words, the economy's structural profile seemed to be in accordance with the opportunities it was facing.

But in spite of all that has been said the growth impulse born in the second half of 2003 faded in the last quarter of 2004. Indeed, the expansion rate showed a substantial reduction in the two following years (2005 and 2006). Apparently we had exchanged a mediocre and brutally unstable growth trajectory for a modest, yet relatively stable one (as shown in Graph III).

Graph III: Industrial Production index with Seasonal Adjustment

(Semestral Movable Averages) $-2002=100$

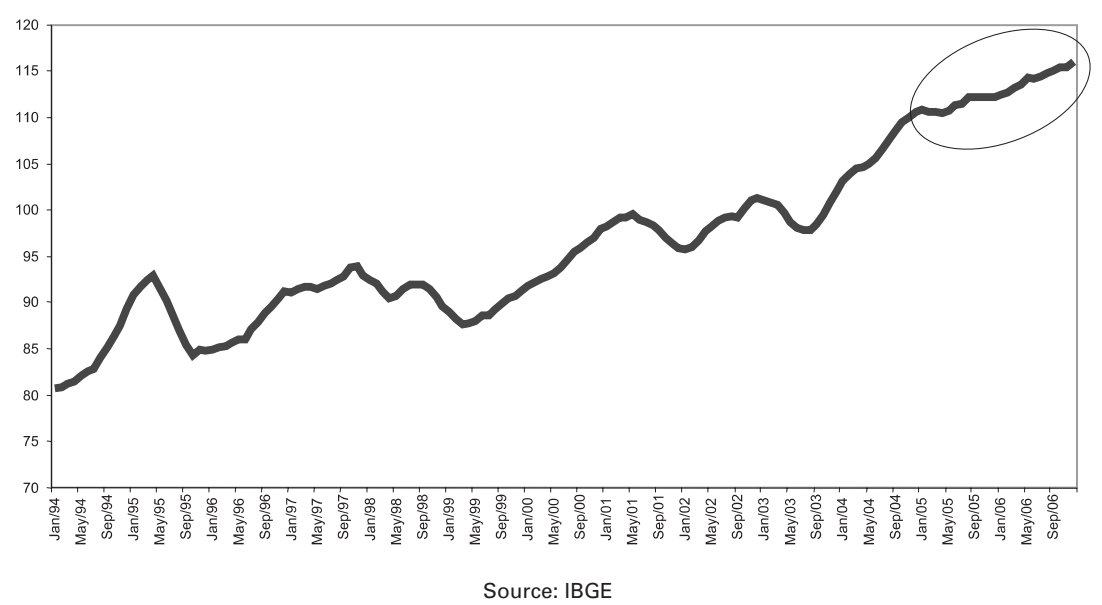

What has just been said is pretty much disappointing in itself and, for many, frankly surprising. After all, low growth has always been understood in this economy as something associated with external restriction and inflationary turbulence. But the economy was now showing current-account surpluses on the order of $1.5 \%$ of GDP per annum, and eliminating the last remaining traces of the turbulence experienced at the transition from FHC to Lula. ${ }^{15}$

The widespread frustration became much deeper, though, when data coming

\footnotetext{
${ }^{15}$ About the relation between instability and (low) growth in Latin America, see ZETTELMEYER, Jeromin, Growth and Reforms in Latin America: a Survey of Facts and Arguments. IMF, 2006.
} 
from other economies proved that growth had become vigorous almost everywhere. If from 1980 to 2000 the average growth of the developing economies was $3.2 \%$ per annum, from 2000 to 2005 this pace leaped to an average of $5 \%$ per annum. ${ }^{16}$ In the case of Brazil, it was not anymore about growing at a pace compatible with so many governmental promises, with the victories achieved at the macroeconomic level, and with the resources and human competences accumulated in the agribusiness, in the 'industrial fortress' and in the sophisticated financial system that the country displays. ${ }^{17}$ In the light of the data, the country was simply and clearly being set behind. And (paradoxically) this was happening in a moment when the Brazilian economy was starting to be considered a serious candidate to the establishment of export platforms of an intermediary technological content. After all, what reasons were hindering the "spectacle of growth" announced by President Lula?

\section{Limits to Growth versus New Course of Growth}

A large group of economists is convinced that in the second half of 2004 the economy was touching the ceiling as far as its productive capacity was concerned. Therefore, demand should be restrained. However, such an understanding omits issues of extreme importance.

At the moment the 'third oil shock' had already begun, together with brutal increases in the prices of several commodities. This time, however, the commodity price shock was accompanied - and cooled off — by "Chinese prices", as far as manufactured goods are concerned. Amongst the most immediate results of this important and historically unique episode one should point out to the moderate raise of the inflation rate (See Table II). It is noticeable the fact that Brazil appears in the table with a remarkably behavior: its rate of inflation in 2006 is no more than a third of the level reached in 2003! But in order to achieve this goal, the nominal interest rate was raised from $16 \%$ to $19.75 \%$ per annum.

\footnotetext{
${ }^{16}$ Global Economic Prospects. Managing the Next Wave of Globalization. World Bank. 2006.

${ }^{17}$ We refer here to growth potential, that is, not to how much the economy grew in the past (and/or as a function of production), but due to the resources and competences that can be mobilized for growth - including, and highlighting, the accumulated knowledge accumulated at the level of enterprises, research institutes, and governmental teams.
} 
Table II: Evolution of Inflation (retail prices), 2000-2006

\begin{tabular}{ccc}
\hline Year & Developing Countries & Brazil \\
\hline 2000 & 4.0 & 6.0 \\
\hline 2001 & 4.7 & 7.7 \\
\hline 2002 & 3.3 & 12.5 \\
\hline 2003 & 4.2 & 9.3 \\
\hline 2004 & 4.4 & 7.6 \\
\hline 2005 & 5.6 & 5.7 \\
\hline 2006 & 5.5 & 3.1 \\
\hline
\end{tabular}

Sources: IMF, IBGE and Brazilian Central Bank

Moreover, it should be stressed that the renewed drop in the economy's growth rate had little to do with the past, when the economy was several times restrained on the edge of the abyss - and only a few believed in the possibility of a new growth cycle. As a matter of fact, in that context a strong increase in the interest rate used to be a quick (and effective) answer to a runaway exchange rate. In 2004, however, substantial evidence signaled the relaxation of the traditional Brazilian difficulties. Indeed, the exchange rate appreciation was already recognized by some analysts as the new tendency. As it has already been suggested, we were possibly on an inflexion point - which might be the threshold of a new growth cycle. But the monetary authorities guided themselves (once again) by what they saw through the rear-view mirror; this time in the middle of a curve.

The orientation that prevailed was fundamentally based on the conventional procedures to evaluate the growth potential of economies. But the Brazilian economy was, at that moment, emerging from 25 years of semi-stagnation. More than that: it was leaving behind three years (2001 to 2003) of high political stress. Besides what, the overall rate of investment was being raised and the manufacturing industry was displaying a truly unsuspected competitive strength!

It is difficult to evaluate the consequences of this sudden deceleration of growth. Thus, for instance, which implications followed from the fact that, once the expansion impetus ceased, the economy faced exchange rate appreciation, with imports being boosted, by the substitution for intermediary and durable consumption goods domestically produced - and no longer, as in 2004, to raise exports and investments ? Last, but not least, it is necessary to point out that the return to mediocre results coincided with the explicit affirmation of China as a leader among emerging economies — including in the competition for multinational investments. In the automotive segment, for example, Brazilian industry was being seen as a serious candidate to host the development of new 
models. ${ }^{18}$ Apparantly, this possibility did not disappear — but it has been damaged by the return to a low growth rate.

To sum up, those who attribute the weakening of the new growth cycle to the exaggerations of monetary policy do have a point. The interest rates prevailing in the country still are an aberration - and it is not easy to eliminate the "fat" accumulated in interest rates, in the harmful stop imposed on the economy in the end of 2004.

But, to understand the transformation of the vibrant growth observed in 2004 into the modest expansion that took place in the two subsequent years notwithstanding the substantial $(33 \%)$ reduction of the interest rate from September 2005 to December 2006 - one have to take into account some questions that have not yet been mentioned.

To start with, it should be stressed that in both 2005 and 2006 the industrial growth, contrary to one of the most consistent characteristics of the Brazilian economy, came to be a brake on GDP growth, as pointed out by Graph IV.

Graph IV: Growth of the GDP and of the Transformation Industry

Rate $(\%)$ accumulated in 4 quartes

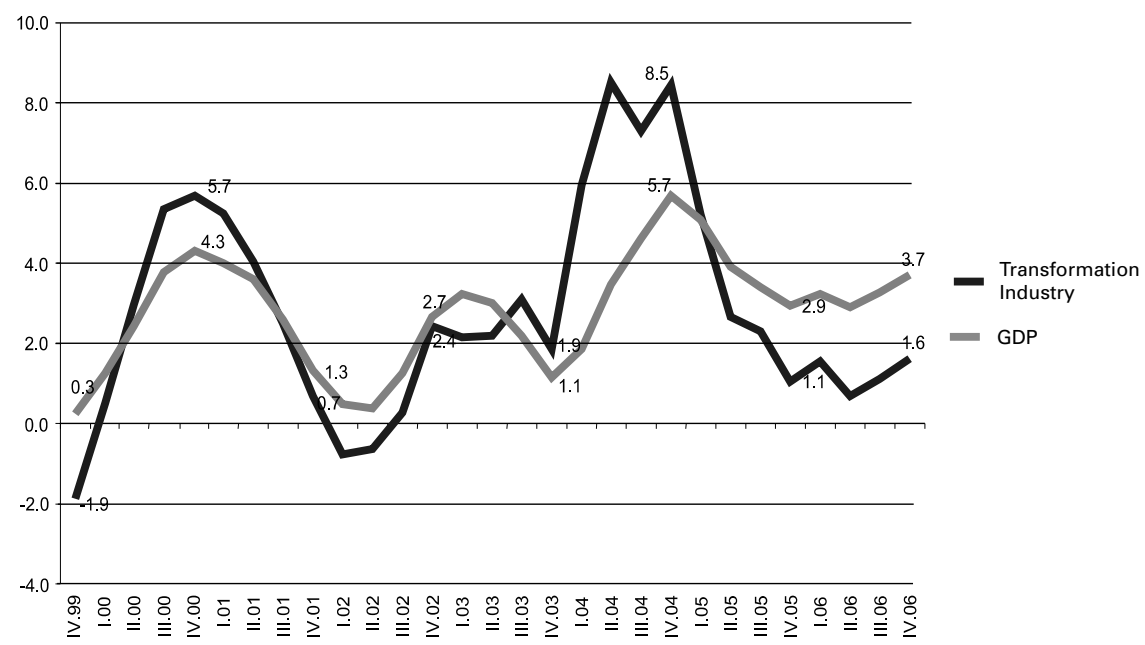

Source: IBGE, Quarterly National Acconunts

Futhermore, Table III (to be compared with table I presented above) puts together some remarkable aspects of the (modest) expansion of industry occurred in 2006.

${ }^{18}$ CONSONI, Flávia Luciane. Da tropicalização ao projeto de veículos: um estudo das competências em desenvolvimento de produtos nas montadoras de automóveis no Brasil. Instituto de Geo-Ciências, Universidade Estadual de Campinas, August 2004. 
Table III: Sectors which contributed to the formation

from $75 \%$ to $80 \%$ of the Industry Growth Rate in 2006

\begin{tabular}{lccc}
\hline Sector & Contribution & $\begin{array}{c}\text { Accumulated } \\
\text { Contribution }\end{array}$ & Weight \\
\hline $\begin{array}{l}\text { Office machines and information } \\
\text { technology equipment }\end{array}$ & 23.3 & 23.3 & 1.4 \\
\hline Extractive industry & 16.4 & 39.7 & 7.0 \\
\hline Machines, devices and electric material & 10.1 & 49.8 & 3.6 \\
\hline Machinery and equipment & 8.5 & 58.3 & 11.4 \\
\hline Food & 6.6 & 64.9 & 2.6 \\
\hline Beverages & 5.9 & 70.8 & 5.9 \\
\hline Basic Metallurgy & 5.4 & 76.2 & 38.6 \\
\hline Other & 23.8 & 100.0 & \\
\hline Total & 100.0 & & 2.7 \\
\hline Memo: & & 98.3 & \\
\hline Industry Growth Rate & & & \\
\hline Real Effective Exchange Rate (93=100) & & & \\
\hline Weight from 1999-2001, & & & \\
\hline
\end{tabular}

Weight from 1999-2001, uptdated by the variation of the production in volume.

The reader will notice that in a two-year time frame, there has been a considerable change in the profile of the industrial growth. Firstly, in the sense that the sectors which explain $75 \%$ to $80 \%$ of industrial growth were reduced from 10 to 7 . Besides, and, above all, because the processing of natural resources acquired a much greater weight: the extractive industry came to represent the second largest contributor to the industrial expansion in general, while basic metallurgy occupies the seventh position. These segments were not even among the top 10 in 2004. Office machines and information technology equipment, in turn, takes up the leadership in terms of contributing to growth. But this reflects the success of a governmental program named Computador para Todos [Computer for All]. By contrast, it must be noted that the two items representing automotive vehicles and machines and equipment (the cornerstones of the 'Brazilian industrial fortress'), which had represented $42.1 \%$ of the country's industrial growth in 2004, (Table I), had their contributions drastically reduced in $2006 .^{19}$

Given the concentration and redistribution experienced by the industrial segments contributing to growth in 2006, we can notice that the outbreak of growth

\footnotetext{
${ }^{19}$ The changes mentioned here were identified and commented on in the BNDES' Sinopse do investimento, August 2006, by CASTRO, Antônio Barros de \& PIRES DE SOUZA, Francisco Eduardo, under the title "Especialização e diversidade na indústria: o desafio contido nos mais recentes dados".
} 
observed in 2004 was not so much simply interrupted, as it was truncated, so to speak. In concrete terms, while the transformation industry only glides (Graph IV), the extractive industry displays excellent results. Domestic demand (consumption + investment), however, increased 5.3\% both in 2004 and in 2006 (!).

\section{GROWTH IN A SINO-CENTRIC MARKET}

\section{Tendencies in the Sino-Centered Economy}

The world economy has been facing serious limitations as regards to the availability of some natural resources, at least since 2003. It is not the first time that this occurs. In modern times, a similar phenomenon was observed around the end of the 1960s, and went on into the first years of the following decade, hastening the so-called 'first oil shock'. The graph below suggests that the new scarcity originated from 2003 on, a violent high in the price of metals and oil.

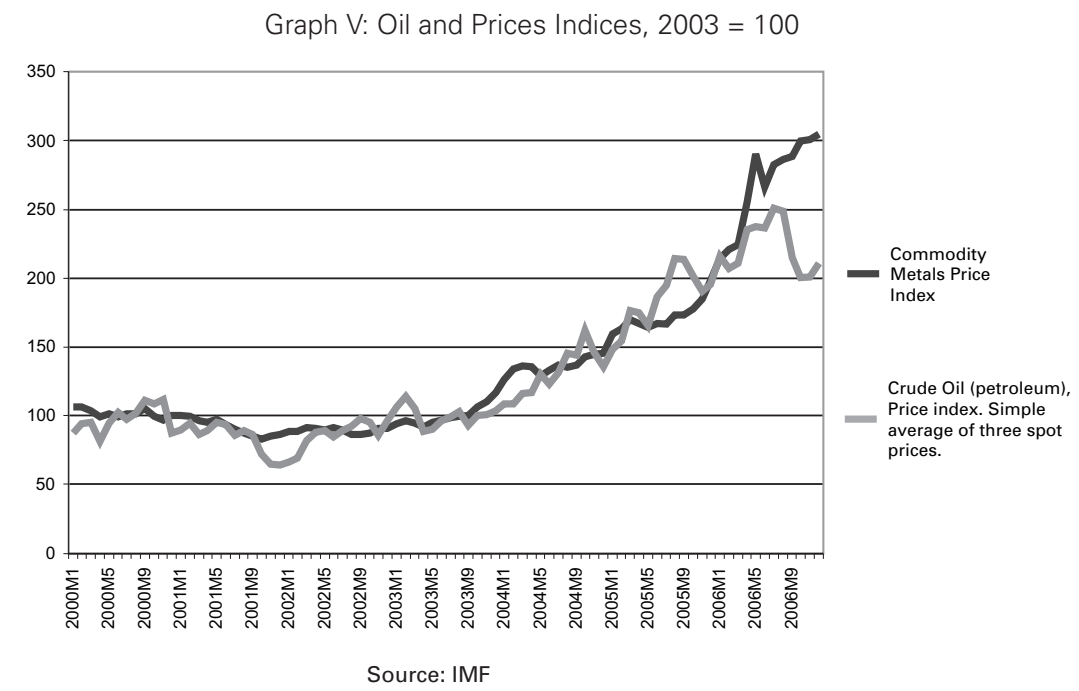

The collision with the natural resources barrier (and/or the capacity of processing them) is, by itself, capable of explaining important current phenomena. Thus, for example, similar to what happened in the first half of the 1970s, several economies well equipped with natural resources had their growth boosted by the extraordinarily positive evolution of their terms of exchange.

The new episode presents important differences, though, when compared with the previous one. (see Table IV). 
Table IV: Latin America and the Caribbean: Termos of interchange $(2000=100)$

\begin{tabular}{lcc}
\hline Countries & 2003 & 2006 \\
\hline Argentina & 107.2 & 111.8 \\
\hline Brazil & 97.0 & 102.4 \\
\hline Chile & 102.8 & 186.9 \\
\hline Colombia & 95.2 & 124.5 \\
\hline Mexico & 98.8 & 107.6 \\
\hline Peru & 102.2 & 150.1 \\
\hline Venezuela & 98.7 & 188.9 \\
\hline Central America & 92.6 & 87.3 \\
\hline Latin America and the Caribbean & 98.6 & 117.5 \\
\hline Source: CEPALBalance Preliminar de America y Caribe. 2006.
\end{tabular}

Source: CEPAL,Balance Preliminar de America y el Caribe, 2006.

The pressure over natural resources this time mainly comes from the emerging economies' explosively increasing consumption of metals and energy. These economies, besides exporting massively to the old industrial countries, host huge population contingents - which are being turned into consumers of industrialized products. This historically unprecedented phenomenon suggests a tendency towards the 'generalization of development'. Amongst its major consequences at least two should be here underlined: the sudden consciousness that some resources, critical to the world economy as we know it, must be considered exhaustible; and the unexpected conversion of demography into a defining factor of the each nation`s economic weight and economic gravitation.

The greatest highlight of this historic transformation is definitely China, what can be observed from several angles. Let us only emphasize a pair of very illustrative data: the Chinese economy, which contributed about half of the increase in the demand for copper and aluminum between 2002 and 2005, was also responsible for $29 \%$ of global economy's growth in the same period. ${ }^{20}$

The well known fact that China started its rapid growth from an extremely low level of income is another characteristic to be emphasized here. Actually, Chinese per capita income, even after over 25 years of rapid growth, is still approximately 6,600 dollars (measured in PPP). ${ }^{21}$ Therefore, if Chinese catch up is not aborted (as the Brazilian catch up was), there is a lot of work to do ahead: it is estimated that the consumption of metals, for example, will only decelerate from an average income situated between 15,000 and 20,000 dollars. This implies that the pressure over the world natural resources is likely to continue for many

\footnotetext{
${ }^{20}$ World Economic Outlook, International Monetary Fund. September 2006.

${ }^{21}$ South Korea and Taiwan also departed from very low levels of average income, but these were (as it has already been said) 'half-nations', which could not develop significant gravitational force.
} 
years - a statement that becomes certainly more evident, if India is included in the picture. ${ }^{22}$ In short, there are good reasons to assume that the prices of metals and, above all, liquid fuels (even if they significantly retreat from the peaks achieved in 2006) may be kept at historically high levels in the next years. Therefore, at least as far as these commodities are concerned, we are apparently not before a mere bubble. ${ }^{23}$

As a final characteristic of this brief stylization, we must add that the economy of the United States - which has been sharing the stage with the Chinese economy - definitely helped to define some of the most striking features of the new context. This topic obviously goes beyond the objectives of this work. Let us remember, however, that the gigantic deficits in the North American current transactions meant, in practice, a condition for the Chinese ascension to happen at a truly overwhelming pace. In fact, the exuberant external demand which presently draws so many emerging economies displays, among its premises, an intense and peculiar interactive game between the United States and China. Besides, what also decisively contributed to the creation of the new frame was the innovative fertility of the North-American companies - supported by a powerful and peculiar national system of innovation, and lubricated by a creative and versatile financial system.

To these characteristics some tendencies can be added. Among them - and as far as the purpose of this study is concerned - the following deserve emphasis:

- the high competitive pressure imposed by the recently emerged - and highly dynamic - low cost manufacturing economies. The growth of the world market for traditional manufactures is being progressively concentrated in these economies, what increases their capacity to attract greenfield investments. As for the raw-material processing units, they will continue to be disseminated worldwide, in their search for areas well provided with natural resources and energy. Firms able to bring to the market an incessant stream of new goods and services will continue to operate plants and do research in the developed world;

- the abundance of international liquidity. From the point of view of prices, the pressures of demand resulting from this frame tend, however, to be mitigated due to the already mentioned low-cost manufacturing production and to the pace acquired by the stream of innovations able to increase efficiency and reduce transaction costs; ${ }^{24}$

\footnotetext{
${ }^{22}$ The almost exclusive reference to China in this text is justified (amongst other reasons) by the fact that, while this country employs approximately 100 million workers in industry, India has an industrial workforce of 7 million individuals. Indeed, from 1985 to 2005, the Chinese foreign trade jumped from $1,6 \%$ to $7,3 \%$ of world trade.

${ }^{23}$ Cf. 2004 World Economic Outlook, Chapter 5: The boom in non fuel commodity prices: can it last?

${ }^{24}$ DELONG, J. Bradford. Productivity Growth in the 2000s. University of California, Berkley 2002.
} 
- the relative ease with which several economies and regions well supplied with natural resources will keep on expanding in the next years. The pressure over natural resources strengthened the comparative advantages of this group, tending to appreciate its assets in general. As it has already been said, a long-lasting world imbalance has apparently been created in several commodities markets. But we are certainly not before a classic cycle, originated in the industrialized centers and which drags, for a relatively short period of time, the so-called peripheral or reflex economies. ${ }^{25}$ In fact, from this point of view also, the present context has no precedent;

- the possibility of catching the so-called 'Dutch disease', by economies which, being well provided with resources the world is in need of, also have a diversified domestic economy. The illness acts through substantial exchangerate appreciation (and/or elevation of nominal wages), which reduces or even turns negative the return from sales of products that do not benefit from the hunger for natural resources. As for the present episode, an aggravating circumstance is that the peripheral manufacturing industries cannot anymore rely on the implicit protection that was historically provided by the high wages paid (and strong market power carried out) by traditional oligopolies. Consequently, there are two movements: some natural resources reach and keep historically unprecedented prices, whereas manufactured final goods tend to be relatively depreciated. And the problem cannot be reduced to the supply of manufactured goods effectively coming from China: even in a relatively closed economy like the Brazilian one, the prices of several products are being more and more dictated by the mere possibility if bringing them from China;

- the decisive reinforcement of a technological agenda, focused on the development of alternatives to fossil fuels and a more efficient use of natural resources. This agenda is strongly connected to environmental issues;

- the increase in the stress with, and instability of, the international political context, either because the sizable incomes derived from natural resources provide countries and regions with the means to search for - in their own

\footnotetext{
${ }^{25}$ RESENDE, Marco Flávio da Cunha \& AMADO, Adriana. "Liquidez internacional e ciclo reflexo: algumas observações para a América Latina". Revista de Economia Política, Volume 27, JanuaryMarch 2007. The issues associated to the dependence on natural resources (the 'resource curse') are at the origin of CEPAL' s defense of the industrialization. In the end of the 1950s, Furtado produced a dark/shady and premonitory report about the Venezuelan case. Typical deformations (including at the political level) associated to the 'resource curse' were recently pointed out by STIGLITZ, Joseph, in his Making Globalization Work. W. W. Norton \& Company, 2006 (chapter 5). For many years, mainstream economics tried to deny the specific difficulties that an emerging economy centered in natural resources tend to face. See, for instance, From Natural Resources to the Knowledge Economy. World Bank, September 2001. The pessimism about the dependence on natural resources is however being restored in the last years.
} 
way - affirmation, ${ }^{26}$ or because of the inevitably growing conflicts related to the safety of supply. This last issue, besides feeding conflicts, reinforces the interest of mature nations in developing technological solutions which might free them from the dependence on imports of certain strategic raw materials.

Once hypothetically admitting, the tendencies that have just been pointed out, it is worth insisting upon the fact that, if the Chinese expansion and its growing openness ${ }^{27}$ were already remarkable and influential before $2003,{ }^{28}$ the substantial devaluation of the renminbi in relation to currencies other than the dollar since that year magnified the so called China-effects. Presently, experts consider that the Chinese currency is between $30 \%$ and $40 \%$ undervalued. And the undeniable evidence of the maladjustment is the exponential increase of the Chinese Current Account surplus, which leaps from 1.3\% of GDP in 2001 to $9.2 \%$ of GDP in 2006 !

The most immediate consequence of the Chinese currency disarray is the corresponding increase in the international competitiveness of goods produced in that country. On the other hand, we must take into account the fact that the (almost) fixed exchange rate policy vis-à-vis the dollar makes it difficult for the Chinese authorities to control the excess in domestic liquidity associated with the explosive external current surplus. ${ }^{29}$ Consequently, the suction of raw materials and energy - in planetary scale - towards China, becomes almost uncontrollable.

Without discussing the serious problems that have just been summarily pointed out, we must add that its confrontation would require a difficult combination of flexible exchange rate with an acceleration of the domestic consumption — which has already been expanding to (insufficient!) $8 \%$ to $9 \%$ per annum. Given the highlighted difficulties - and the political unwillingness to face the exchange rate issue so far - everything suggests the need to face the inbuilt tendencies of a sino-centric world market, boosted by the maladjustment of the Chinese currency.

\footnotetext{
${ }^{26}$ Something unthinkable in the two last decades of the last century is also part of this context: the fast cancellation of foreign debts, including by pre-payment, from the part of countries which were, until very recently, plunged into severe crises derived from the high foreign indebtedness.

${ }^{27}$ The average tax which burdens the imports in China dropped from $42.9 \%$, in 1992, to $12.3 \%$, in 2002.

${ }^{28}$ Given the speed with which China absorbs new technologies, the average productivity of labor in that country increases more than the average in the other countries. About the increase in the Chinese industrial productivity, see the January 2006 article by RODRIK, Dani. "What is so special about China's export?", available on the author's website.

${ }^{29}$ GOLDENSTEIN, Moris \& LARDY, Nicholas. "China's Exchange Rate Policy Dilemma”. American Economic Review, May 2006.
} 


\section{Implications for the Brazilian Case}

The changes triggered by the trade liberalization of the early 1990s were (finally) being translated into substantial results in the first years of this century. In other words, from the industrial point of view, we could say that the Brazilian manufacturing industry was (spontaneously) essaying a modified re-edition of the NIC model, ${ }^{30}$ experimented with acknowledged success, from the second half of the 1960s to the first shock of the oil crisis (1973-4). ${ }^{31}$

A major problem - until very recently ignored — was that China, as far as manufacturing is concerned, was taking a course similar to (yet obviously more ambitious than) the Brazilian one. We mainly refer here to the production (by subsidiaries of multinational companies, as well as by domestic firms) of a similar set of standard articles - with the same (simplified) technologies - as the ones which were being produced in the large industrial centers. ${ }^{32}$ Consequently a sizable part of the Brazilian industry was doomed to face serious problems.

First, because the Chinese industry, which still have a substantial advantage as far as labor costs are concerned (both wages and manufacturing productivity have been growing in China at double digit rates), developed growing advantages regarding the scales of production and infrastructure costs - field where the latter China invests about $10.5 \%$ of its GDP .

Furthermore, because, taking advantage of the fact that off shoring to China might be extremely attractive, the Chinese government conditioned the implantation of multinational branches in the country to the acceptance of local partners. Such a policy, combined with the extremely high domestic overall investment rate (supposedly higher than $40 \%$ of the GDP) certainly contributed to the rapid dissemination of modern technology in the country.

Finally a reference must be made to the consequences of the renmimbi devaluation (accompanying the dollar). This fact, combined with pro-active policies coming from provinces, cities and other Chinese political entities is, in the last few years, decidedly thickening Chinese industrial chains. Indeed, the traditional prevalence of assembling over effective manufacturing is being overcome in that country $;^{33}$ and, paradoxically, China is presently completing a

\footnotetext{
${ }^{30}$ The Newly Industrialized Countries. Challenges and Opportunity for OECD Industries. OECD, 1998.

${ }^{31}$ BATISTA, Jorge Chami \& ALMEIDA DOS SANTOS. "Industrialização da pauta de exportação" (1964 e 1974). Revista Brasileira de Economia Politica, April/June 2007.

${ }^{32}$ For a characterization of the Chinese path - and some striking differences to the Korean one - see LIU, Xielin. China's Development Model: An Alternative for technological Catch-up. Hiotsubashi University, liuxielin@hotmailcom, March 2005; See also KROEBER, Arthur. Inovação: Todo o Errado. Carta da China, Edição Especial, April 2007. Conselho Empresarial Brasil-China.

${ }^{33}$ CUI, Li \& HUSSAIN SYED, Murtaza. Is China Changing its Stripes? The Shifting Structure of China's External Trade and its Implications. International Monetary Fund, April 2007
} 
sui generis process of import substitution. In this way, due (also) to chain economies, China's competitive capacity is spreading into new segments.

As for the Brazilian case, the industrial sector was, until very recently, submitted to the ups and downs typical, of the domestic market. But in contrast to what happened during the first experiment with the NIC route, a more innovative pattern of behavior - frequently associated with the growth of exports - started to be practiced by several industrial firms. ${ }^{34}$ It was in this difficult but improving context that the renmimbi's actual average exchange rate dropped, between 2004 and 2006, 29\% in relation to the Brazilian currency (in other words, Chinese imports became, in principle, $29 \%$ cheaper in Brazil). An explosion of imports followed, at a staggering $47 \%$ growth rate a year.

Under such circumstances, the Brazilian economy begins to pay a price for having developed and somehow consolidated (in the 1990s), a highly diversified industrial system. And the new industrial and technological policy (announced in March 2004), meritorious under several criteria, could not meet the new challenge. Its horizon was the strengthening of sectors that generate and disseminate technical progress (semiconductors, software, capital equipment and pharmaceutical products), together with a general support for innovative initiatives. And its major supposition (originally not perceived as such) was that the leadership in the industrial field was, by and large, still held by the triad United States-EuropeJapan. This, however, had ceased to be a fact.

In contrast to what happened in Brazil, the adaptation of several LatinAmerican and African economies to the deep changes brought about by the $21^{\text {st }}$ century was quite easy. The more natural resources they had, and the more they had previously (since commercial liberalization) renounced to manufacturing, the easier was such an adaptation. Ultimately, in such cases, there was practically no choice to be made. In other words, if the economies had already accepted the role of raw-material and energy providers before the emergence of China, more reasons would they have now to keep on following the same route.

In Brazil, however, the issue is present in a quite diverse way. After the successful restructuring accomplished in the 1990s, it is difficult to even imagine that the economy could adopt a sort of classical international division of labor. Both in the agribusiness and the industrial sector, Brazil relies today on competences accumulated and matured through time, often under adverse conditions. Moreover, the country has the world's fifth population - of which $90 \%$ is considered urban.

Given what has been said it is quite clear that the second liberalization (see Graph VI) now being experienced by the Brazilian economy poses a number of challenges. We can take it for granted that in certain activities a new round of restructuring initiatives has been made necessary. But here we face an important

\footnotetext{
${ }^{34}$ ARBIX, Glauco, SALERNO, Mario Sérgio \& DE NEGRI, João Alberto. “A nova competitividade da indústria e o novo empresariado". In VELLOSO, João Paulo dos Reis (Org) O Desafio da China e da Índia. A resposta do Brasil. José Olympio, 2005.
} 
question. Do changes in the relative prices occurred in the last years, which rewards natural resources and punishes manufactured products, require, predominantly, a reallocation of factors? Or should they be faced - to a great extent - through the development of existing capabilities, often at the same activities and even firms? Economists usually only consider one answer: the reallocation (or reassignment) of resources. Did new signs appear in the market? The (spontaneous) reactions should come in terms of transfers. Labor and capital will be displaced to other activities in search of a more attractive constellation of resources, given the new set of relative prices. It is as if the real side of the economy had to be 'refounded', whenever facing a substantial change in relative prices.

Graph VI:

Degree of Openesess of the Brazilian Economy: Export + imports/GDP

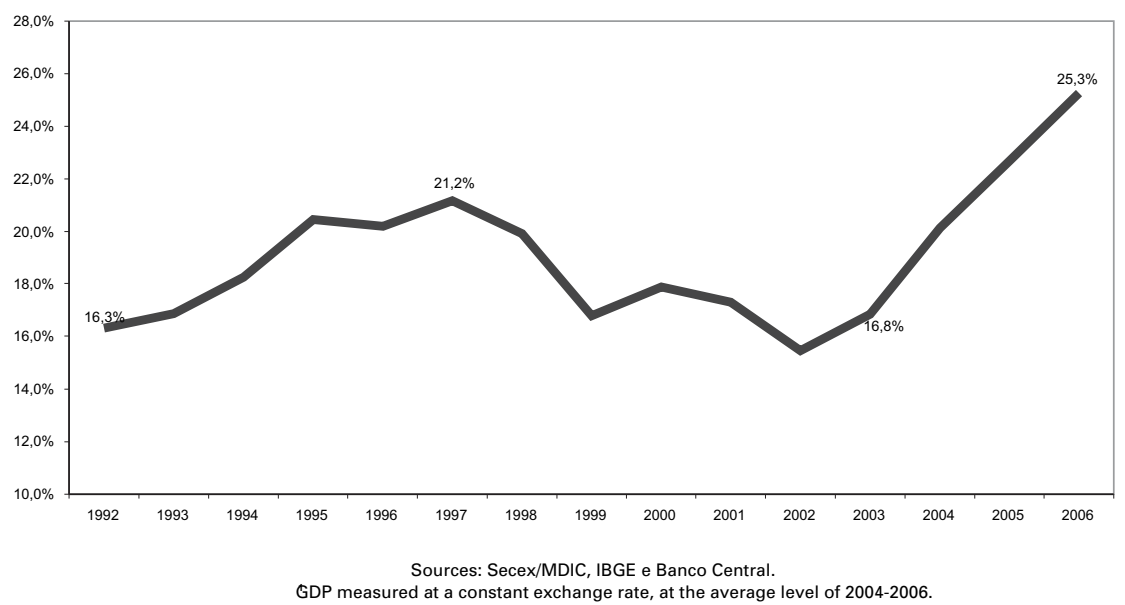

We depart from a different point of view, whose basic presupposition is the idea that companies currently practice what might be called a bounded use of their own resources. That is to say, facing a major challenge (the resumption of sustainable growth can certainly be one), a possible solution might be to extract new and different 'services' from the resources already found within firms. This perception is naturally complemented by another: technologies, as a rule, are not on the shelf, waiting to be used - rather they are temporary solutions to be reshaped, adapted and developed. ${ }^{35}$

The previous arguments seem to be specially persuasive in the present Brazilian situation. Amongst other reasons, for being an economy that was extensively

${ }^{35}$ PENROSE, Edith. The Theory of the Growth of the Firm. Oxford University Press, 1995; CORIAT, Benjamin \& DOSI, Giovanni. "The Nature and Accumulation of Organizational Competences and Capabilities”. Revista Brasileira de Inovação, July/December 2002. 
subjected to deep falls, strong recoveries and sudden changes in the institutional setting. Under such circumstances it is quite reasonable to suppose that a number of opportunities has been perceived, through the ups and downs of the semistagnation period, that were not properly exploited. ${ }^{36}$

But there still is an additional reason for the view proposed here to acquire special meaning in the Brazilian case. The economy has been accumulating modern skills for about five decades. This effort has actually resulted in some noticeable outcomes within the electric-mechanical field, in the exploitation of deep waters oil, and in the aeronautics industry. The new setting may possibly become an exceptional opportunity to deepen and to develop old and new solutions. The theme will be briefly explored in the final item of the article.

\section{The National Program for the Acceleration of Growth (PAC) as the Preamble for a New Agenda of Policies}

The Brazilian economy growth performance continued to show, until March 2007 , and according to the available data, results typical of the last quarter of century: an increase of $2.3 \%$ in the GDP, in 2005 , followed of a modest expansion of $2.9 \%$ in 2006 .

The anemic result of $2.3 \%$ (later corrected to $2.9 \%$ ) contributed to transforming the demand for growth into a public outcry. This fact, combined with the certainty shared by some members of the government about the possibility of a more robust performance of the economy, led to the elaboration of a program for the acceleration of growth.

The prominence attributed to large infra structural projects in the new growth program was already present in previously announced plans - but they were, by and large, not implemented. This is understandable: while the Brazilian economy was under suspicion of imminent insolvency — and with the government diligently trying to reduce the roles of the state - no program requiring a major involvement of the state had much chance to be executed. Furthermore, given the slow average growth presented by the Brazilian GDP, demand pressures could be somehow attended, with the same (deteriorating) facilities.

Regarding transportation - and logistics in general - there was indeed, during the last quarter of century, noticeable deterioration of the legacy left by the phase of rapid growth. And this was a consequence not only of sharply declining investments, but also of the fact that semi-stagnation never meant immobilization: the economic map of the country was deeply changed from 1980 to the present. Indeed, from the economic point of view, the western part of the state of Bahia, as well as some areas of Mato Grosso and Tocantins practically

\footnotetext{
${ }^{36}$ About the 'advantages of semi-stagnation' referred here, see CASTRO, Antonio Barros. A Hipótese do Crescimento Rápido e Sustentado, op.cit.
} 
did not exist in 1980. More than this, even in the economically mature states an intensive transference of productive activities was observed, from metropolitan areas to the hinterland ${ }^{37}$ - causing additional demands, not adequately satisfied, on the infrastructure in the country.

Seen by many as a mere repackaging of previously existing projects, PAC may come to be an important step towards overcoming a historical phase, in which the government's political energy was dissipated by its effort to promote macroeconomic adjustments and structural reforms. In order to meet its goals, the program intensively turns to the investment capacity of state owned companies, that had simply not been involved in major governmental policies since the privatization campaign. This change faced great initial resistance, especially from those who used to see state owned enterprises as inhabitants of a limbo area, from which they would only find their way out, when privatized.

Besides, by making use of the very companies it controls, the government directly involves itself in energizing the economy in its search for growth. Thus, investment regained - at the government internal and operational level - its status of a central theme. Moreover, by demanding programs and projects to public institutions, as well as by establishing goals and deadlines for their fulfillment, PAC increased the demand for skills that had remained idle or were even lost during the semi-stagnation phase. As a matter of fact, investments in infrastructure constitute the sort of activity that pre-supposes - and induces a long-term view. Goals, on the other hand, induce cooperation and convergence in public and private decisions, possibly increasing the systemic rationality.

It is convenient to stress that of the total estimated investment included in the PAC ( $\mathrm{R} \$ 504$ billion), nearly $40 \%$ is supposed to come from the private sector. This requires, besides the improvement of certain regulatory regimes, continuous efforts aiming at cooperation and articulation of (public and private) decisions.

In short, the PAC - even if it is to experience only a partial implementation - will be contributing to the elimination of merely reactive and predominantly non cooperative behavior, typical of the semi-stagnation long period. If so, it will contribute to the building of a new governmental culture - which could well be unfolded to similar programs in agriculture, science and technology, and so forth.

But the Program is undeniably dominated by the government's concern in recovering investment and consequently "unblock" (in the official discourse) growth. ${ }^{38}$ However, practically coinciding with the launching of PAC the devastatingly competitive and extraordinarily voracious Chinese economy multiplied its impacts over the Brazilian economy. In the emerging context, eliminating the bottlenecks inherited from semi-stagnation, as well as the widely

\footnotetext{
${ }^{37}$ SABÓIA, João. Geração de emprego industrial nas capitais e no interior do Brasil. SENAI, Brasília, 2005.

${ }^{38}$ Primeiro Balanço do PAC, janeiro a abril de 2007. [PAC - First Evaluation, January to April 2007].
} 
spread fear to invest continued to be a necessary agenda. But this agenda omits new and important issues. In a word, the traditional Brazilian industrial structure has to be somehow reshaped to escape some menaces, and - mainly — to exploit new opportunities. Fundamentally, it is no more a question of (merely) raising investment and expanding the infrastructure. Some amongst the newest questions are: how much will come from the same (existing) firms, with or without consolidation? what should be tried of effectively new? what should be the new vision of the desired future? And finally, what might be the new agenda of cooperative transformation between state agencies, private investors, companies, technological institutes and Universities? To cope with these questions a preliminary distinction should be made, between a predominantly reactive scenario, and a strategically conceived scenario. 